\title{
Cathodoluminescence of Juína Diamonds
}

\author{
Gaspar, J.C. '; Teixeira, N.A. ${ }^{2}$ and Steele, I.M. ${ }^{3}$
}

1 - Instituto de Geociências, Universidade de Brasília, 70910-900 Brasilia, DF, Brazil.

2 - 1. Rio Tinto Desenvolvimentos Minerais Ltda. SCS Ed. Morro Vermelho, 10 andar - Brasília - DF, Brazil

3 - Department of Geophysical Sciences, University of Chicago, 5734 S. Ellis Ave, Chicago, IL 60637, USA

The Cretaceous Juína kimberlite province is located at the northern border of the Parecis Palaeozoic basin, which is underlain by the Mesoproterozoic sialic Rio Negro-Juruena mobile belt (Teixeira et al., this volume). The Juína diamonds occur in alluvium (São Luiz, Mutum, Porcão, Juininha, Rio Vermelho, and Samambaia rivers) and in some kimberlite bodies. Almost all alluvial diamondiferous rivers, with a total production of more than 8 million carats, drain the Chapadão plateau, a thin unit made up of immature clay-rich sediments with numerous granite and gneiss pebbles. These cretaceous sediments are rich in kimberlite indicator minerals, and possibly were deposited as wet mud flows (flash flood?) in active faults in the sialic basement. The diamonds are predominantly industrial and very seldom are found in stones up to $480 \mathrm{ct}$. It is possible to state, based on mantle xenolith, garnet and spinel xenocrysts, that the lithosphere beneath the Rio NegroJuruena Mobile Belt is composed mainly of lherzolite and eclogite, reset at the Mesoproterozoic and that, consequently, the Juína diamonds should not be associated with a depleted harzburgite Archean keel. The last conclusion is also supported by $\mathrm{Sm} / \mathrm{Nd}$ data (Bizzi and Pimentel, oral comunication).

A general description of macro-diamond population from Juína kimberlites and alluvial deposits can be summarised as follows: a) dodecahedral to irregular shapes are prevalent but octahedral, aggregate and macle also occur; b) predominant colors are brown and light brown, although white, milky, yellow and pink colors occur; c) the majority of stones have many inclusions; d) etched surface features are common in the form of frost, striations, dissolution lamellae, roll relief, trigons and pits. Cathodoluminescense (CL) studies were made for $\sim 100$ stones from alluvium (São Luíz and Duas Barras rivers) and from kimberlite intrusions. The diamonds were polished to give a flat surface, cleaned and observed under a CL microscope. Digital backscattered electron and CL images were acquired using the electron microprobe at the University of Chicago.

Juína stones show a deep blue CL color, sometimes with a strong intensity contrast between zones. Locally, yellow colors are present. It is possible to identify primary features such as octahedral growth which is repeatedly truncated by resorption surfaces since the first observed growth lines at the onset of the diamond formation. Their crystallization history is complicated with very complex patterns of growth and resorption developed during many different stages. Some diamonds show several nuclei which coalesced into a single large crystal. No regular pattern of concentric growth was observed. Actually, even our the best quality stone, which is a dodecahedroid, does not display concentric growth. All studied diamonds are crystal fragments and not whole crystals. Brecciation and annealing textures are also present in some stones.

One diamond shows yellowish-green "lines" that could be interpreted as crystallographic controlled exsolution or dislocations. This portion of the stone was imaged in a High Resolution Ion Microprobe (HRSIMS) for $\mathrm{N}$ and $\mathrm{H}$. Neither element was detected and thus the "lines" do not appear to correlate with $\mathrm{N}$ or $\mathrm{H}$ at the detection level of this instrument. The yellow "lines" are 
rather interpreted as dislocations or slip planes. Such features can indicate that this diamond has undergone plastic deformation during its mantle residence while the breccia textures indicate stages of brittle deformation.

It seems that a combination of intermittent stages of crystallization, resorption, and shearing produced this diamond population. The history of formation of the Juína diamonds explains their low gem quality. The gem quality of alluvial diamonds is better than the intrusion stones (due to selection through transport) and the former tend to be more homogeneous based on CL images. The textural features of both populations, however, are essentially similar, indicating that the alluvial stones came from the intrusions.

The Juína diamonds are known to have been formed in the Transition Zone or possibly in the Lower Mantle, due to the sub- $650 \mathrm{~km}$ mineralogy assemblage included in diamonds from the São Luiz river (majorite, periclase-wüstite solid solution, $\mathrm{Ni}, \mathrm{Cr}$, and $\mathrm{Al}$ levels in the oxide phases, and $\mathrm{SiC}$ ) (Widing et al., 1991; Harris et al. 1997; Harte et al., 1994). Compared to the diamonds from cratonic areas, the Juína diamonds present a much more complex formation history. A basic question is whether the complex growth history of Juina diamonds can be explained by their ultra deep source, as indicated by the São Luiz inclusions. If so, how does one relate to the other? The most obvious possibility is to relate the observed growth and deformation features to the large mantle section, and consequently different physico-chemical conditions, through which these diamonds were transported. If they came from the lower mantle, as indicated by the mineral inclusions, the transition zone and the asthenosphere to lithosphere boundary, are the most evident regions of changing conditions through which they have travelled.

Besides Juína, other occurrences such as Monastery and Jagersfontein show evidence of kimberlitic asthenospheric protomelts at depths greater than $670 \mathrm{~km}$ (Haggerty, 1991). According to Haggerty (1991) all these bodies would have intruded craton edges; regions that are privileged locus for plume induced magmatic activity. We are analyzing the possibility that the Juina kimberlites and diamonds had a global evolution linked to the Nazca plate journey to the Transition Zone.

\section{Acknowledgements}

We thank RTDM and SOPEMI for supplying the diamonds and allowing the publication of results.

\section{REFERENCES}

Harte, B. and Harris, J.W., 1994, Lower mantle mineral associations preserved in diamonds: Mineral Mag. V. A 58, p. 384-385.

Harte, B., Hutchison, M.T. and Harris, J.W., 1994, Trace element characteristics of the lower mantle: an ion probe study of inclusions in diamonds from São Luiz, Brazil: Mineral Mag., v. A 58, p. 386-387.

Harris, J., Hutchison, M.T., Hursthouse, M., Light, M. and Harte, B., 1997, A new tetragonal silicate mineral occurring as inclusions in lower-mantle diamonds: Nature, v. 387 p. 486-488.

Wilding, M.C., Hart, M.C., and Harris, J.W., 1991, Evidence for a deep origin for São Luiz Diamonds: Fifth International Kimberlite Conference, Extended Abstracts, CPRM p. 456-458. 
Haggerty, S.E., 1991, Emplacement and implications of ultra-deep xenoliths and diamonds from the transition zone: Fifth International Kimberlite Conference, Extended Abstracts, CPRM. p. 157159.

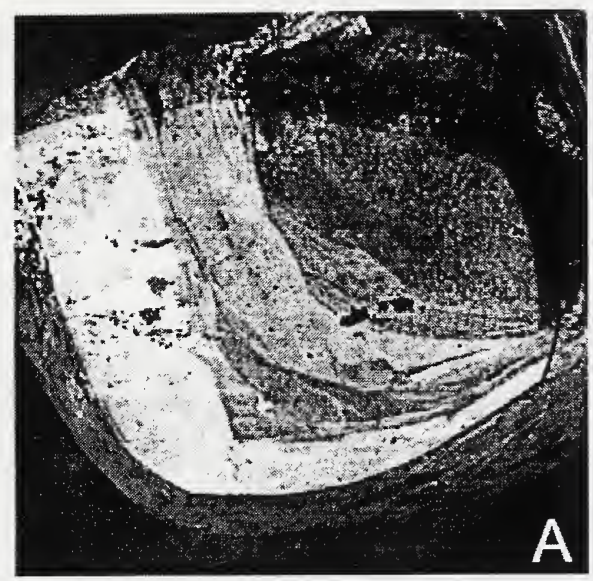

Figure 1 - Digital $\mathrm{Cl}$ images of Juína diamonds.

Observe that stones are crystal fragments.

A - Alternate sequence of growth and resorption in two crystal faces.

B - Complex pattern of crystallization and resorption.

C - Breccia-like texture in the central portion of is followed by a complex stage of growth and resorption. The outer shell shows a later regular growth stage.
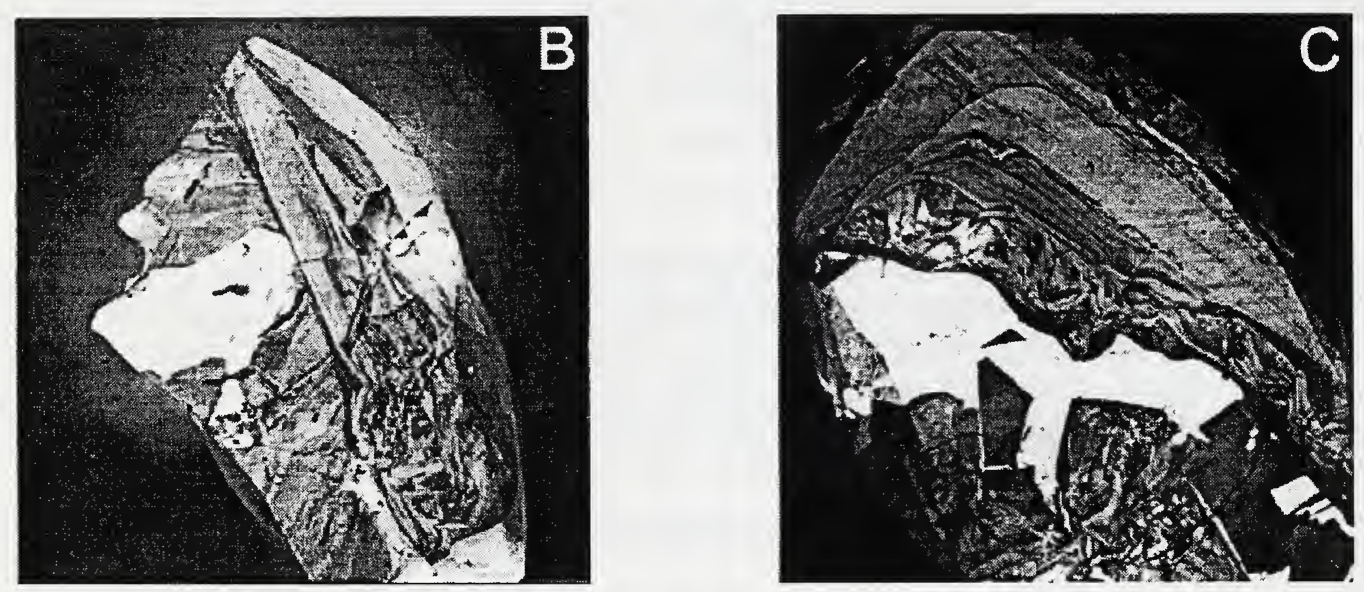